Sistem Pakar Rekamendasi Peminjaman Buku Di Perpustakaan Sekolah Tinggi Teknologi Adisutjipto Yogyakarta Dengan Metade Penyaringan Kolaboratif

\title{
SISTEM PAKAR \\ REKOMENDASI PEMINJAMAN BUKU DI PERPUSTAKAAN SEKOLAH TINGGI TEKNOLOGI ADISUTJIPTO YOGYAKARTA DENGAN METODE PENYARINGAN KOLABORATIF
}

\author{
Piniel Romulia Hasibuan, Anton Setiawan Honggowibowo, Hero Wintolo \\ Jurusan Teknik Informatika \\ Sekolah Tinggi Teknologi Adisutjipto Yogyakarta \\ informatika@stta.ac.id
}

\begin{abstract}
Library of Sekolah Tinggi Teknologi "Adisutjipto" Yogyakarta has developed rapidly according to the world development and the increasing number of library members and book collections that are owned by the library. The billing system which is running now is able to serve books borrowing and returning services to the members, but is unable to provide an alternative book recommendation according to a certain book borrowed by a member.

Book Recommendation Expert System for Library of Sekolah Tinggi Teknologi "Adisutjipto" Yogyakarta with collaborative filtering method uses historic book borrowing data, building, and maintaining profiles of the members of library based on the major taken by the member and the favourite reading topic of each member in order to provide some alternatives when a member borrow a book.

After passing the test period, this system is claimed effective to be used in the library, make the library service become more efficient in providing alternative book recommendations, and is able to provide user satisfied alternative book recommendations.
\end{abstract}

Keywords: Expert System, Lending Book Recommendations, Collaborative Filtering Method

ABSTRAK

Perpustakaan Sekolah Tinggi Teknologi “Adisutjipto" Yogyakarta berkembang pesat seiring perkembangan jaman dan bertambahnya jumlah anggota perpustakaan serta koleksi buku yang dimiliki. Sistem billing yang dimiliki oleh perpustakaan sudah mampu melayani peminjaman dan pengembalian buku, namun belum dapat memberikan rekomendasi buku alternatif yang dapat dipinjam oleh seorang anggota yang meminjam buku tertentu.

Sistem Pakar Rekomendasi Peminjaman Buku di Perpustakaan Sekolah Tinggi Teknologi "Adisutjipto" Yogyakarta dengan metode penyaringan kolaboratif memanfaatkan data-data historis peminjaman buku dan membentuk serta mengelola profil setiap anggota perpustakaan berdasarkan jurusan dan topik bacaan kegemaran anggota, sehingga ketika seorang anggota perpustakaan meminjam sebuah buku tertentu, sistem ini dapat memberikan beberapa rekomendasi buku alternatif yang dapat dipinjam oleh anggota tersebut.

Setelah melalui tahap uji coba, sistem ini dinyatakan efektif apabila diterapkan di perpustakaan Sekolah Tinggi Teknologi “Adisutjipto" Yogyakarta, dapat meningkatkan efisiensi kinerja perpustakaan dalam memberikan rekomendasi buku alternatif kepada pengunjung, serta dapat memberikan hasil rekomendasi buku alternatif yang memuaskan.

Kata Kunci: Sistem Pakar, Rekomendasi Peminjaman Buku, Metode Penyaringan Kolaboratif 

Sistem Pakar Rekomendasi Peminjaman Buku Di Perpustakaan Sekolah Tinggi Teknologi Adisutjipto Yogyakarta Dengan Metade Penyaringan Kolaboratif

\section{Pendahuluan}

Sistem pakar berawal dari keinginan manusia untuk menggunakan kemampuan yang dimiliki oleh para ahli/ pakar tanpa adanya keterbatasan waktu dan tempat.Dengan adanya sistem pakar, semua pengetahuan yang dimiliki oleh seorang pakar dapat direkam dalam komputer dan digunakan untuk memecahkan persoalan-persoalan yang biasanya memerlukan keahlian pakar tersebut. Sistem pakar telah berkembang sangat pesat seiring dengan perkembangan teknologi informasi dan meningkatnya kebutuhan akan sistem pakar tersebut, dan kini sistem pakar telah digunakan dalam berbagai bidang, seperti: kedokteran, pendidikan, penelitian, bisnis, dan sebagainya. Perpustakaan Sekolah Tinggi Teknologi Adisutjipto Yogyakarta didirikan bersamaan dengan berdirinya Sekolah Tinggi Teknologi Adisutjipto Yogyakarta, dan perpustakaan ini telah berkembang pesat, baik dari segi penambahan jumlah buku, pemanfaatan sistem informasi, peningkatan kualitas pegawai, dan meningkatnya jumlah anggota. Perpustakaan telah menerapkan sistem billing untuk peminjaman buku, namun sistem billing ini masih memiliki keterbatasan dalam hal ketidaktersediaan sistem rekomendasi untuk peminjaman buku. Oleh karena itu, diperlukan suatu sistem yang dapat memberikan rekomendasi buku yang akan dipinjam oleh pengunjung perpustakaan. Proses rekomendasi akan dilakukan dengan menggunakan metode penyaringan kolaboratif yang akan membagi pengunjung perpustakaan ke dalam kelompok-kelompok dengan kebutuhan serupa, sehingga sistem yang baru nanti dapat memprediksi preferensi pengguna berdasarkan kecocokan antara profil pengguna sekarang dengan profil pengguna lama yang tersimpan di dalam database.

Dari uraian latar belakang masalah di atas dapat dirumuskan sebuah masalah yaitu bagaimana cara merekomendasikan buku alternatif yang dapat dipinjam ketika seorang pengunjung perpustakaan meminjam suatu buku tertentu dengan metode penyaringan kolaboratif.

\section{Landasan Teori}

Terdapat dua kelompok pendekatan dalam mendefinisikan sistem, yaitu yang menekankan pada prosedur dan pendekatan yang menekankan pada komponen atau elemen yang dimiliki sistem. Pendekatan sistem yang lebih menekankan pada prosedur mendefinisikan sistem sebagai suatu jaringan kerja dari prosedur-prosedur yang saling berhubungan, berkumpul bersama-sama untuk melakukan suatu kegiatan atau untuk menyelesaikan suatu sasaran yang tertentu. Menurut Jerry Fitzgerald, Ardra F. Fitzgerald dan Warren D. Stallings, Jr., prosedur adalah urut-urutan yang tepat dari tahapan-tahapan instruksi yang menerangkan apa (what) yang harus dikerjakan, dan siapa (who) yang mengerjakannya mengerjakannya, kapan (when) dikerjakan dan bagaimana (how) mengerjakannya.

Pendekatan sistem yang lebih menekankan pada elemen atau komponennya mendefiniskan sistem sebagai kumpulan dari elemen-elemen yang berinteraksi untuk mencapai suatu tujuan tertentu

Kedua kelompok definisi tersebut adalah benar dan tidak bertentangan, yang berbeda adalah cara pendekatannya. Pendekatan sistem yang merupakan kumpulan elemen-elemen atau komponen-komponen atau subsistem-subsistem merupakan definisi yang lebih luas.Definisi ini lebih banyak diterima, karena kenyataannya suatu sistem dapat terdiri dari beberapa subsistem atau sistem bagian.

\section{Konsep Sistem Pakar}

Sistem pakar adalah suatu program komputer yang dirancang untuk mengambil keputusan seperti keputusan yang diambil oleh seorang atau beberapa orang pakar. Kemampuan yang dimiliki oleh suatu sistem pakar sesuai dengan bidang kepakaran dari ahli/ pakar yang menjadi sumber basis pengetahuan (knowledge base) dari sistem pakar tersebut. 
Menurut Marimin (1992), "sistem pakar adalah sistem perangkat lunak komputer yang menggunakan ilmu, fakta, dan teknik berpikir dalam pengambilan keputusan untuk menyelesaikan masalah-masalah yang biasanya hanya dapat diselesaikan oleh tenaga ahli dalam bidang yang bersangkutan."

Dalam penyusunannya, sistem pakar mengkombinasikan kaidah-kaidah penarikan kesimpulan (inference rules) dengan basis pengetahuan tertentu yang diberikan oleh satu atau lebih pakar dalam bidang tertentu. Kombinasi dari kedua hal tersebut disimpan dalam komputer, yang selanjutnya digunakan dalam proses pengambilan keputusan untuk penyelesaian masalah tertentu.

Menurut Staugaard (1987), sebuah sistem pakar tersusun atas tiga buah modul utama, yaitu:

1. Modul Penerimaan Pengetahuan (Knowledge Acquisition Mode) Sistem berada pada modul ini, pada saat sistem tersebut menerima pengetahuan dari pakar. Proses mengumpulkan pengetahuan-pengetahuan yang akan digunakan untuk pengembangan sistem dilakukan dengan bantuan knowledge engineer. Peran knowledge engineer adalah sebagai penghubung antara suatu sistem pakar dengan pakarnya.

2. Modul Konsultasi (Consultation Mode)

Pada saat sistem berada pada posisi memberikan jawaban atas permasalahan yang diajukan oleh pengguna, sistem pakar berada dalam modul konsultasi.Pada modul ini, pengguna berinteraksi dengan sistem dengan menjawab pertanyaan-pertanyaan yang diajukan oleh sistem.

3. Modul Penjelasan (Explanation Mode)

Modul ini menjelaskan proses pengambilan keputusan oleh sistem, yakni bagaimana suatu keputusan dapat diperoleh.

Komponen utama pada struktur sistem pakar (Hu et al, 1987) meliputi:

1. Basis Pengetahuan (Knowledge Base)

Basis pengetahuan merupakan inti dari suatu sistem pakar, yaitu berupa representasi pengetahuan dari pakar.Basis pengetahuan tersusun atas fakta dan kaidah.Fakta adalah informasi tentang objek, peristiwa, atau situasi. Kaidah adalah cara untuk membangkitkan suatu fakta baru dari fakta yang sudah diketahui. Menurut Gondran (1986) dan Utami (2002), basis pengetahuan merupakan representasi dari seorang pakar, yang kemudian dapat dimasukkan ke dalam bahasa pemrograman khusus untuk kecerdasan buatan (misalnya PROLOG atau LISP) atau shell sistem pakar (misalnya EXSYS, PC-PLUS, CRYSTAL, dan sebagainya.)

2. Mesin Inferensi (Inference Engine)

Mesin inferensi berperan sebagai otak dari sistem pakar. Mesin inferensi berfungsi untuk memandu proses penalaran terhadap suatu kondisi, berdasarkan pada basis pengetahuan yang tersedia. Di dalam mesin inferensi terjadi proses untuk memanipulasi dan mengarahkan kaidah, model, dan fakta yang disimpan dalam basis pengetahuan dalam rangka mencapai solusi atau kesimpulan. Dalam prosesnya, mesin inferensi menggunakan strategi penalaran dan strategi pengendalian. Strategi penalaran terdiri dari strategi penalaran pasti (exact reasoning) dan strategi penalaran tak pasti (inexact reasoning).Exact reasoningakan dilakukan jika semua data yang dibutuhkan untuk menarik suatu kesimpulan tersedia, sedangkan inexact reasoning dilakukan pada keadaan sebaliknya. Strategi pengendalian berfungsi sebagai panduan arah dalam melakukan prose penalaran.Terdapat tiga teknik pengendalian yang sering digunakan, yaitu forward chaining, backward chaining, dan gabungan dari kedua tehnik pengendalian tersebut.

3. Basis Data (Database) 
Basis data terdiri atas semua fakta yang diperlukan, dimana fakta-fakta tersebut digunakan untuk memenuhi kondisi dari kaidah-kaidah dalam sistem. Basis data menyimpan semua fakta, baik fakta awal pada saat sistem mulai beroperasi, maupun fakta-fakta yang diperoleh pada saat proses penarikan kesimpulan sedang dilaksanakan. Basis data digunakan untuk menyimpan data hasil observasi dan data lain yang dibutuhkan selama pemrosesan.

4. Antarmuka Pemakai (User Interface)

Fasilitas ini digunakan sebagai perantara komunikasi antara pemakai dengan sistem.

Representasi pengetahuan adalah suatu teknik untuk merepresentasikan basis pengetahuan yang diperoleh ke dalam suatu skema/ diagram tertentu sehingga dapat diketahui relasi/ keterhubungan antara suatu data dengan data yang lain. Teknik ini membantu knowledge engineer dalam memahami struktur pengetahuan yang akan dibuat sistem pakarnya.

Terdapat beberapa teknik representasi pengetahuan yang sering digunakan dalam pengembangan suatu sistem pakar, yaitu:

\section{Rule-Based Knowledge}

Pengetahuan direpresentasikan dalam suatu bentuk fakta (facts) dan aturan (rules).Bentuk representasi ini terdiri atas premis dan kesimpulan.

2. Frame-Based Knowledge Pengetahuan direpresentasikan dalam suatu bentuk hierarki atau jaringan frame.

\section{Object-Based Knowledge}

Pengetahuan direpresentasikan sebagai jaringan dari obyek-obyek. Obyek adalah elemen data yang terdiri dari data dan metode (proses).

4. Case-Base Reasoning

Pengetahuan direpresentasikan dalam bentuk kesimpulan kasus (cases).

Kategori permasalahan sistem pakar secara umum, antara lain:

1. Interpretasi, yakni membuat kesimpulan atau deskripsi dari sekumpulandata mentah.

2. Prediksi, yakni memproyeksikan akibat-akibat yang dimungkinkan darisituasi-situasi tertentu.

3. Diagnosis, yakni menentukan sebab malfungsi dalam situasi kompleks yang didasarkan pada gejala-gejala yang teramati.

4. Desain, yakni menentukan konfigurasi komponen-komponen sistem yang cocok dengan tujuan-tujuan kinerja tertentu yang memenuhi kendala-kendala tertentu.

5. Perencanaan, yakni merencanakan serangkaian tindakan yang akan dapat mencapai sejumlah tujuan dengan kondisi awal tertentu.

6. Debugging dan repair, yakni menentukan dan menginterpretasikan cara-cara untuk mengatasi malfungsi.

7. Instruksi, yaknimendeteksi dan mengoreksi defisiensi dalam pemahaman domain subyek.

8. Pengendalian, yakni mengatur tingkah laku suatu lingkunganyang kompleks.

9. Selection, yakni mengidentifikasi pilihan terbaik dari sekumpulan (list) kemungkinan.

10.Simulation, yakni pemodelan interaksi antara komponen-komponen sistem.

11.Monitoring, yakni membandingkan hasil pengamatan dengan kondisi yang diharapkan.

\section{Sistem Rekomendasi Berbasis Web}

Sistem rekomendasi berbasis web adalah sistem cerdas yang dapat mengidentifikasi minat pengunjung website dari penggunaan data yang telah ada dan berdasarkan hal tersebut membuat usulan untuk meningkatkan loyalitas pengunjung serta mencapai tingkat konversi atau retensi yang lebih tinggi. 
Profil pengguna merupakan dasar untuk merancang sebagian besar fungsi sistem rekomendasi. Fungsi-fungsi tersebut dibagi dalam dua kategori utama, yaitu: pembuatan dan pengelolaan profil, serta eksploitasi dan rekomendasi profil (Montaner, 2003). Sistem perlu membangun dan memelihara profil pengguna dan kemudian mengolah informasi yang berguna untuk membuat suatu rekomendasi.

\section{Penyaringan Kolaboratif}

Penyaringan kolaboratif menggunakan konsep segmentasi pasar (membagi pengunjung ke dalam kelompok-kelompok dengan kebutuhan serupa) dalam memprediksi preferensi pengguna. Intinya ialah membandingkan profil pengguna sekarang (misalnya sejarah peminjaman, perilaku browsing) dengan profil pengguna di bagian lain populasi untuk mengidentifikasi pengguna pada database yang mungkin mirip dengan pengguna sekarang. Minat yang ditemukan dari pengguna serupa digunakan untuk menyimpulkan minat pengguna sekarang, dan rekomendasi dibuat berdasarkan hal tersebut.

Data yang dikumpulkan dalam sistem penyaringan kolaboratif umumnya terdiri atas matriks dua dimensi pengguna-produk yang barisnya menyatakan pengguna, dan kolomnya menyatakan produk, misalnya buku.Preferensi pengguna dari setiap produk direpresentasikan oleh nilai pada sel dalam matriks. Sayangnya, urutan organisasi data ini sering menyebabkan penskalaan dan masalah performa yang buruk pada saat himpunan data menjadi sangat besar, misalnya pada saat jutaan pengguna dan produk direpresentasikan dalam matriks penggunaproduk. Di samping itu, ketika semakin banyak pengguna yang menolak untuk memberikan evaluasi produk atau cenderung hanya meminjam sejumlah kecil item dalam katalog produk, matriks pengguna-produk pun cenderung sangat ramping dan menjadi tidak efisien pada saat diaplikasikan pada skala besar. Masalah ini sebagian mungkin dapat diatasi dengan menggunakan teknik reduksi dimensionalitas, seperti pengelompokan dan analisis komponen utama.

Secara umum, sistem penyaringan kolaboratif membuat rekomendasi dengan memprediksi preferensi seseorang sebagai nilai bobot dari preferensi orang lain dalam himpunan bagiannya, dengan bobot yang disesuaikan terhadap kekuatan korelasi di antara dua individu. Perlu diperhatikan bahwa pendekatan ini memiliki beberapa keterbatasan. Karena algoritmanya bekerja dengan mengelompokkan pengunjung ke dalam himpunan bagian, rekomendasi buruk dapat saja diberikan kepada pengguna yang seleranya berbeda dengan sebagian lain dari populasi. Sistem juga gagal untuk member pengguna alasan rekomendasi.Selain itu, karena algoritmanya hanya dapat digunakan pada saat database berisi data preferensi item tertentu, maka tidak dapat dibuat rekomendasi untuk produk baru yang belum digunakan atau dinilai oleh seorangpun.Misalnya, sebagian besar algoritma penyaringan kolaboratif tidak dapat merekomendasi pengguna apakah suatu buku baru adalah buku yang bagus. Gambar 1 memperlihatkan arsitektur sistem rekomendasi kolaboratif pada sebuah website e-commerce.

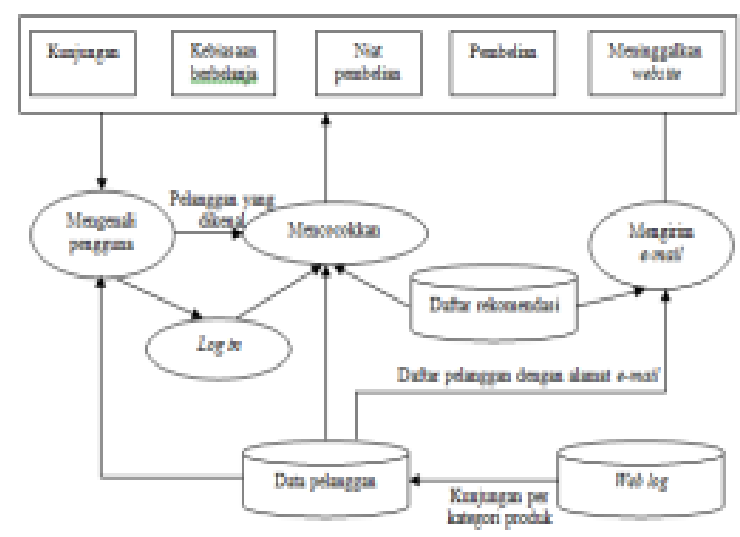


Gambar 1. Arsitektur sistem rekomendasi kolaboratif pada sebuah web e-commerce

\section{Perancangan Sistem Diagram Konteks}

Terdapat 2 entitas, yaitu: (admin dan pengguna). Yang pertama adalah admin.Untuk dapat masuk ke dalam sistem, admin harus login terlebih dahulu.Kemudian admin dapat mengolah data yang terdapat pada menu admin, termasuk data buku dan data pengguna sistem.Yang kedua adalah pengguna umum, yang dapat mengirimkan data-data pribadinya, preferensi, serta kritik dan saran (feedback) untuk meningkatkan kualitas hasil rekomendasi.

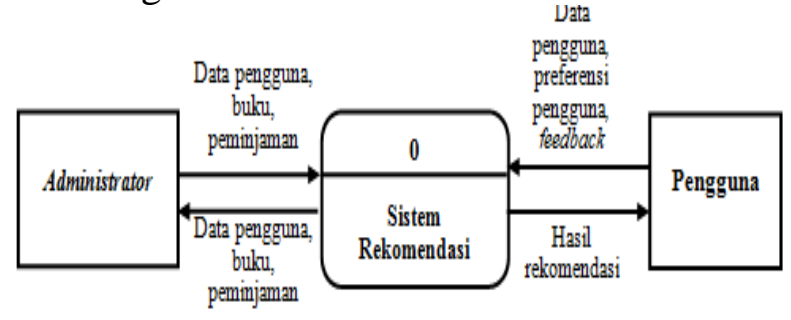

Gambar 2. Diagram konteks sistem rekomendasi peminjaman buku

\section{DAD Level 1}

Sistem yang akan dibangun memiliki empat buah proses, yaitu: pengolahan data, yakni proses yang meliputi proses menambahkan data, menampilkan, mengubah, maupun menghapus datadata yang ada di dalam database. Proses kedua adalah menampilkan data buku. Dalam hal ini, yang menampilkan data buku adalah pengguna sistem secara umum, bukan seorang administrator. Proses ketiga adalah peminjaman buku yang dilakukan dengan mengisikan judul buku yang akan dipinjam oleh pengguna sistem. Proses keempat adalah pengolahan data pengguna yang meliputi pendaftaran pengguna baru, dan pemberian umpan balik (feedback) setiap kali pengguna menerima suatu rekomendasi buku. Proses pertama membutuhkan hak akses tingkat administrator, sedangkan proses yang lain dapat diakses langsung oleh semua pengguna sistem. Apabila terdapat kesalahan saat pengisian data diri maupun saat pengguna hendak melakukan pengubahan data diri, pengguna harus menghubungi administrator untuk melakukan pembaharuan data. 


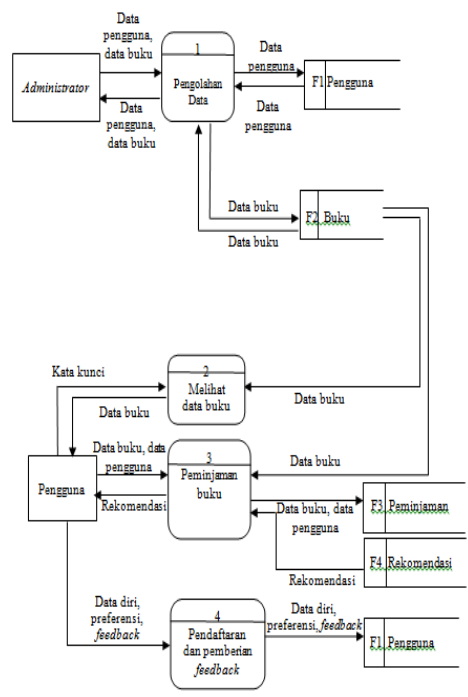

Gambar 3. DAD Level 1

\section{DAD Level 2 Proses 1}

Seorang admin yang terverifikasi dapat mengakses dan memodifikasi semua data yang tersimpan dalam database.

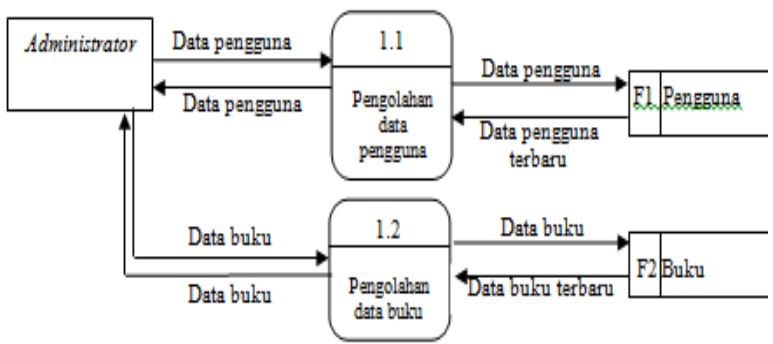

\section{Gambar 4. DAD Level 2 Proses 1}

\section{DAD Level 2 Proses 2}

Seorang pengguna dapat melihat data buku yang ada dengan memasukkan kata kunci sesuai dengan judul buku, nama pengarang, ataupun penerbit buku tersebut.

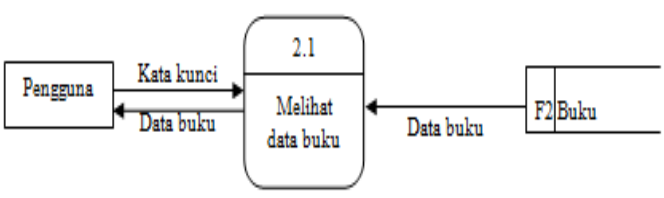

Gambar 5. DAD Level 2 Proses 2

\section{DAD Level 2 Proses 3}

Seorang pengguna dapat meminjam buku di perpustakaan dengan memberikan data dirinya dan data buku yang akan dipinjam. Apabila pengguna tersebut meminjam 2 buah buku, maka data peminjaman tersebut akan disimpan ke dalam tabel rekomendasi. Namun, apabila pengguna 
meminjam hanya satu buku, maka sistem akan memberikan rekomendasi berdasarkan data historis yang tersimpan dalam tabel rekomendasi.

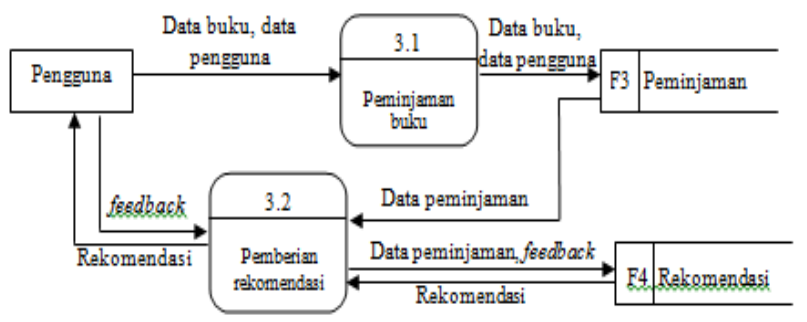

Gambar 6. DAD Level 2 Proses 3

\section{DAD Level 2 Proses 4}

Pengguna perpustakaan yang terus bertambah mengharuskan sistem untuk dapat menambahkan pengguna baru ke dalam database. Pengguna baru dapat mendaftarkan diri ke dalam sistem dengan mengisikan data diri, meliputi: nomor induk mahasiswa (nim), nama, jenis kelamin, agama, alamat, nomor telepon, tempat, tanggal lahir, jurusan, dan topik bacaan kegemaran pengguna yang bersangkutan. Untuk perubahan data, pengguna harus mengubungi administrator sistem untuk menjamin bahwa hanya pengguna yang bersangkutan saja yang dapat melakukan pengubahan/ pembaharuan data.Selain itu, pengguna juga dapat meberikan umpan balik (feedback) untuk meningkatkan kualitas hasil rekomendasi yang dihasilkan oleh sistem, serta untuk melaporkan adanya kejanggalan (bug) saat pengguna menggunakan sistem.

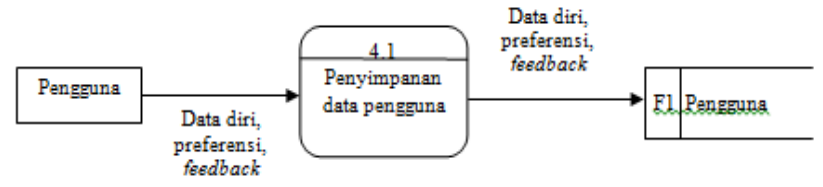

Gambar 7. DAD Level 2 Proses 4

\section{Perancangan Basis Data}




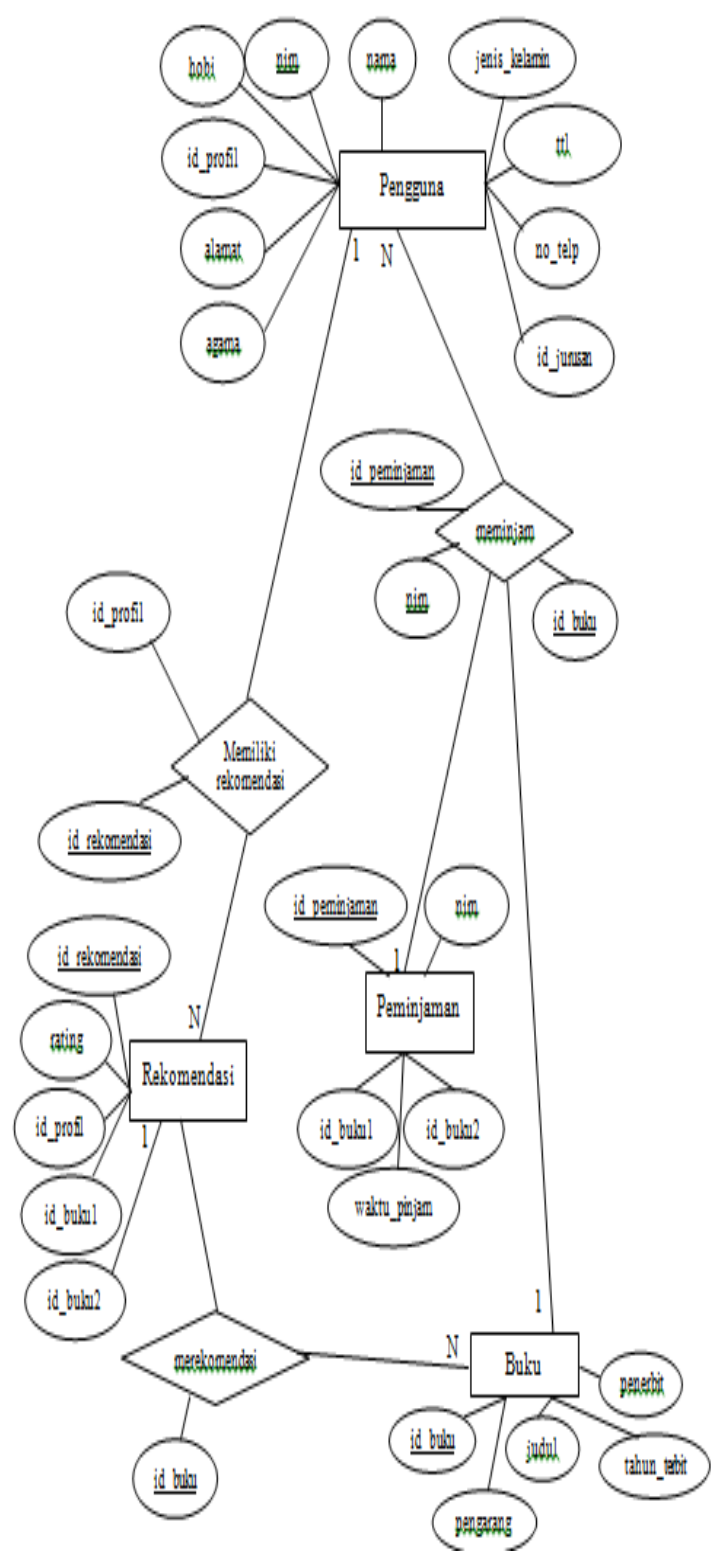

Gambar 8. ERD system

Perancangan basis data merupakan suatu tahapan untuk memenuhi kebutuhan akan informasi dari pengguna dan sistem, untuk menyediakan struktur informasi yang natural dan mudah dimengerti oleh pengguna, serta mendukung kebutuhan pemrosesan dan beberapa obyek kinerja dari suatu sistem basis data.Perancangan ERD bertujuan untuk memudahkan pemahaman tentang hubungan (relasi) antar tiap tabel yang ada dalam basis data.Gambar 8 memuat informasi mengenai Entity Relationship Diagram sistem.

\section{Perancangan Diagram Alir Sistem}

Flowchart merupakan diagram alir dari proses penyelesaian masalah yang disusun secara sistematis. Dalam aplikasi sistem rekomendasi peminjaman buku di perpustakaan STTA Yogyakarta, penyelesaian permasalahan dapat digambarkan pada diagram alir (flowchart) pada gambar 9. 
Sistem Pakar Rekomendasi Peminjaman Buku Di Perpustakaan Sekolah Tinggi Teknologi Adisutjipto Yogyakarta Dengan Metade Penyaringan Kolaboratif

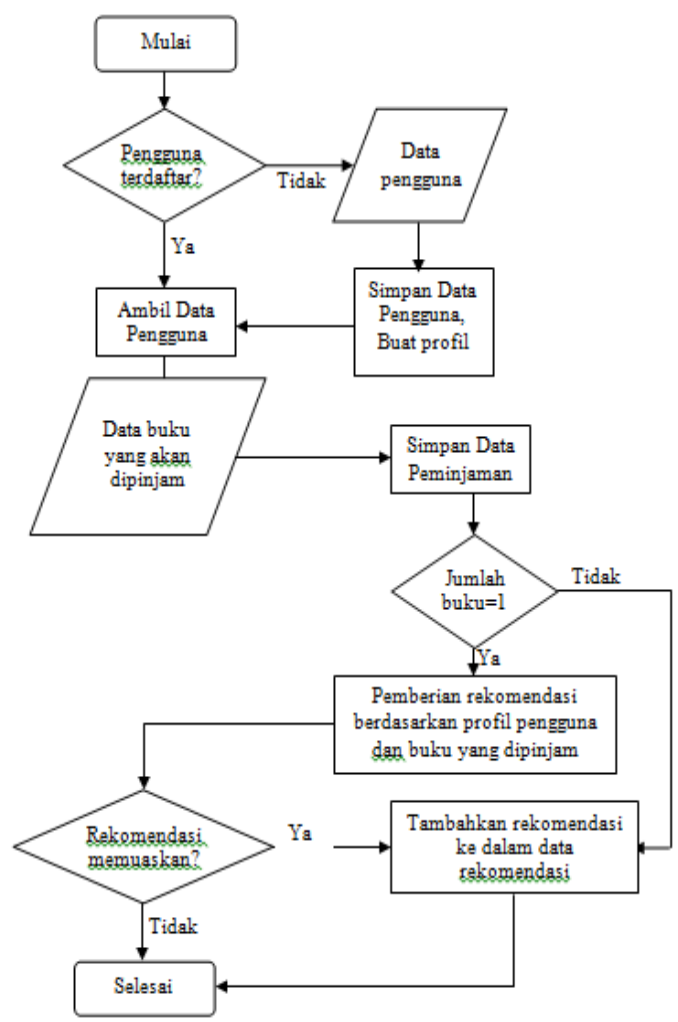

Gambar 9. Diagram alir sistem

\section{Perancangan Aturan}

Sistem pakar merupakan sistem yang berdasarkan pada aturan-aturan sebagai prosedur penyelesaian permasalahan (Gondran, 1986).Demikian halnya dengan sistem pakar rekomendasi peminjaman buku di perpustakaan STT "Adisutjipto" Yogyakarta dengan metode kolaboratif ini.Adapun aturan-aturan yang digunakan dalam sistem ini meliputi aturan-aturan untuk pembentukan profil pengguna dan aturan-aturan untuk memberikan rekomendasi buku kepada pengguna berdasarkan buku yang dipinjam dan profil pengguna tersebut.

Dalam melakukan pengelompokan terhadap pengguna sistem, sistem ini menerapkan aturanaturan sebagai berikut.

Rule 1: IF hobi baca teknologi informasi dan telekomunikasi AND jurusan teknik informatika atau teknik elektro THEN profil 1.

Rule 2: IF hobi baca teknologi informasi dan telekomunikasi AND jurusan teknik penerbangan atau teknik mesin THEN profil 2.

Rule 3: IF hobi baca teknologi informasi dan telekomunikasi AND jurusan teknik industry THEN profil 3 .

Rule 4: IF hobi baca kedirgantaraan AND jurusan teknik informatika atau teknik elektro THEN profil 2 .

Rule 5: IF hobi baca kedirgantaraan AND jurusan teknik penerbangan atau teknik mesin THEN profil 4 .

Rule 6: IF hobi baca kedirgantaraan AND jurusan teknik industri THEN profil 5. Rule 7: IF hobi baca dunia perindustrian dan perdagangan AND jurusan teknik informatika atau teknik elektro THEN profil 3.

Rule 8: IF hobi baca dunia perindustrian dan perdagangan AND jurusan teknik penerbangan atau teknik mesin THEN profil 5.

Rule 9: IF hobi baca dunia perindustrian dan perdagangan AND jurusan teknik industri THEN profil 6 .

Compiler 
Rule 10: IF hobi baca musik dan kesenian AND jurusan teknik informatika atau teknik elektro THEN profil 7.

Rule 11: IF hobi baca musik dan kesenian AND jurusan teknik penerbangan atau teknik mesin THEN profil 8 .

Rule 12: IF hobi baca musik dan kesenian AND jurusan teknik industri THEN profil 9.

Rule 13: IF hobi baca lainnya THEN profil 10.

Dari aturan-aturan di atas, dapat diketahui teknik yang digunakan oleh sistem untuk mengelompokkan pengguna sistem.Sebagai contoh, seorang pengguna dengan data diri seperti pada Tabel 5.

Tabel 5. Tabel Contoh Pengelompokkan Pengguna

\begin{tabular}{|c|c|}
\hline Jenis Data & Nilai Data \\
\hline NIM & 06030013 \\
\hline Nama Mahasiswa & Piniel Romulia Hasibuan \\
\hline Jenis Kelamin & Laki-laki \\
\hline Tempat, tanggal lahir & Mataram, 01 April 1988 \\
\hline Agama & Kristen Protestan \\
\hline Alamat & J1. Pelem Lor No. 8, Banguntapan \\
\hline No. Telepon & 0856404444476 \\
\hline Hobi Baca & Teknologi informasi dan telekomunikasi \\
\hline Jurusan & Teknik informatika \\
\hline
\end{tabular}

Dari data pada tabel 5 dan aturan pengelompokan pengguna yang ada, dapat disimpulkan bahwa pengguna tersebut akan tergolong ke dalam kelompok profil 1, yakni kelompok pengguna yang gemar membaca buku dengan topik teknologi informasi dan telekomunikasi, serta menjadi mahasiswa jurusan teknik informatika.

Untuk menghasilkan suatu rekomendasi, sistem ini menerapkan aturan-aturan berikut ini.

Rule 1: IF buku pertama dengan kelompok profil pengguna ada dalam daftar rekomendasi THEN rekomendasi buku adalah maksimum tiga buah buku kedua dengan rating tertinggi dalam daftar rekomendasi.

Rule 2: IF buku pertama dengan kelompok profil pengguna tidak ada dalam daftar rekomendasi THENIF buku kedua dengan kelompok profil pengguna ada dalam daftar rekomendasi THEN rekomendasi buku adalah maksimum tiga buah buku pertama dengan rating tertinggi dalam daftar rekomendasi.

Rule 3: IF buku kedua dengan profil pengguna tidak ada dalam daftar rekomendasi THEN rekomendasi adalah maksimum tiga buah buku dengan rating tertinggi untuk kelompok profil pengguna.

Dari aturan-aturan di atas, dapat diketahui teknik yang digunakan oleh sistem untuk mengelompokkan pengguna sistem.Sebagai contoh, seorang pengguna dengan kelompok profil 1 dan data rekomendasi buku seperti pada Tabel 6.

Tabel 6. Tabel Data Rekomendasi Buku 


\begin{tabular}{|c|c|c|}
\hline id_buku1 & id_buku2 & rating \\
\hline 45 & 43 & 5 \\
\hline 45 & 44 & 6 \\
\hline 45 & 46 & 8 \\
\hline 50 & 45 & 4 \\
\hline 119 & 45 & 3 \\
\hline
\end{tabular}

Dengan aturan yang ada, maka hasil rekomendasi yang akan muncul apabila seorang pengguna dengan kelompok profil 1 meminjam buku dengan kode buku 45 adalah buku dengan kode 46, 44, dan 43.

\section{Implementasi dan Analisa Sistem}

Setelah pembuatan sistem selesai, maka dilakukan pengujian terhadap sistem yang dilakukan dalam dua cara, yakni pengujian secara teoritik maupun pengujian secara praktek, yakni pengujian langsung kepada para calon pengguna sistem, yakni para mahasiswa STT Adisutjipto Yogyakarta.

Menurut A. Kumar (2010), "sebuah sistem rekomendasi membandingkan profil pengguna terhadap suatu karakteristik referensi dan mencari prediksi rating yang akan diberikan oleh seorang pengguna terhadap suatu item yang belum mereka pertimbangkan." Menurut Paolo Buono (2000), "sebuah komponen personalisasi membangun dan mengeksploitasi model-model atau profil-profil dari semua pengguna yang berinteraksi dengan sistem."

Setelah pengguna mendaftarkan diri, maka sistem akan mengolah data-data pribadi pengguna dan mengelompokkan pengguna berdasarkan aturan tersebut, dan apabila pengguna melakukan peminjaman sebuah buku, maka sistem akan menggunakan data-data historis peminjaman buku yang pernah terjadi sebelumnya dan memadukannya dengan data profil pengguna yang melakukan peminjaman buku untuk menghasilkan sebuah rekomendasi buku yang berkaitan dengan profil pengguna dan buku yang dipinjam oleh pengguna.

Hal inilah yang menjadi keunikan tersendiri dari metode penyaringan kolaboratif sebagaimana diungkapkan oleh Buono (2000), "rekomendasi yang dihasilkan oleh penyaringan kolaboratif bisa berarti suatu kurva pembelajaran yang panjang, karena pada mulanya ketika jumlah pengguna sedikit, kualitas rekomendasi adalah rendah.Hasil rekomendasi ini secara bertahap meningkat seiring dengan bertambahnya jumlah pengguna yang berpartisipasi." Semakin banyak pengguna, dan semakin banyak peminjaman buku yang terjadi, maka daftar rekomendasi pun akan semakin banyak jumlahnya, dan dengan demikian akan menghasilkan kualitas rekomendasi yang semakin berkualitas.

\section{Pengujian Secara Praktek}

Dari uraian sebalumnya, dapat diambil kesimpulan bahwa jumlah data yang ada di dalam daftar rekomendasi akan sangat menentukan kualitas hasil rekomendasi yang diberikan oleh sistem. Oleh karena itu, dalam tahap pengujian sistem secara langsung, diambil sample seratus sepuluh orang mahasiswa STT "Adisutjipto" Yogyakarta untuk mewakili seluruh mahasiswa STT "Adisutjipto" Yogyakarta.Jumlah ini dianggap cukup memenuhi syarat untuk mewakili keseluruhan mahasiswa yang ada, karena mencakup hampir sepuluh persen dari populasi 
mahasiswa STT “Adisutjipto" Yogyakarta berdasarkan pada hasil wawancara dengan staf akademik. Diagram alir untuk proses uji coba melibatkan pengguna diberikan dalam gambar 13.

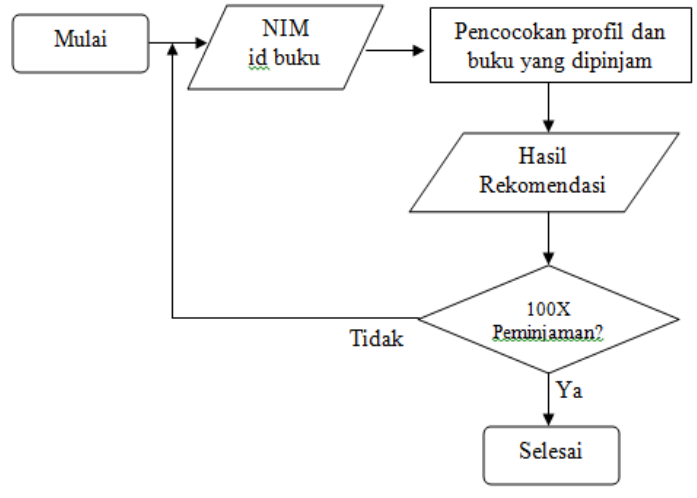

Gambar 13. Diagram alir proses uji coba sistem

\section{Hasil Pengujian}

Dari seluruh data yang terkumpul, diperoleh grafik tingkat efektifitas sistem berdasarkan jajak pendapat yang diisi oleh pengguna sistem seperti pada gambar 14, yakni 96,6\% reponden menyatakan sistem efektif apabila diterapkan di perpustakaan STT Adisutjipto Yogyakarta, sedangkan 3,6\% responden menyatakan sistem tidak efektif. Dari pengujian yang sama mengenai tingkat efisiensi sistem apabila diterapkan di perpustakaan STT Adisutjipto Yogyakarta, diperoleh hasil $100 \%$ responden menyatakan bahwa sistem efisien.Hal ini ditunjukkan pada gambar 16. Dari pengujian yang sama, diperoleh tingkat kepuasan pengguna terhadap sistem seperti ditunjukkan pada gambar 18 , yakni 39,1\% menyatakan sangat puas, $50,6 \%$ menyatakan cukup puas, 1,1\% menyatakan kurang puas, 1,1\% menyatakan tidak puas terhadap kinerja sistem.

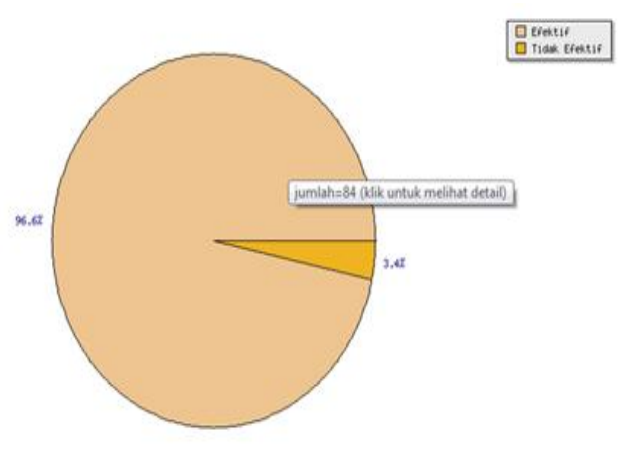

Gambar 14. Tingkat Efektifitas Sistem

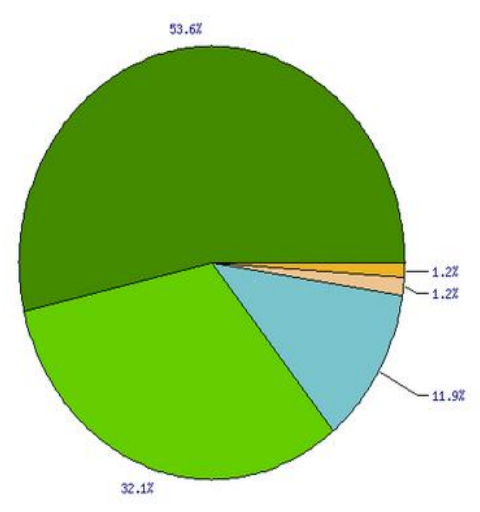

Gambar 15. Detail Tingkat Efektifitas Sistem Per Jurusan
Teknik Informatika Teknik Imdustri Teknik Mesin 

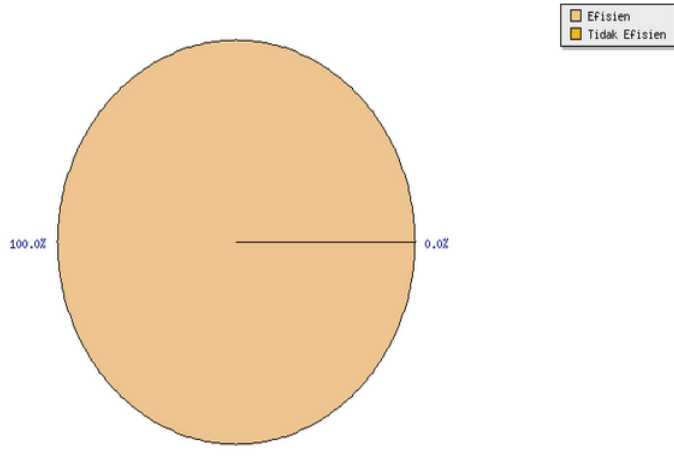

Gambar 16. Tingkat Efisiensi Sistem

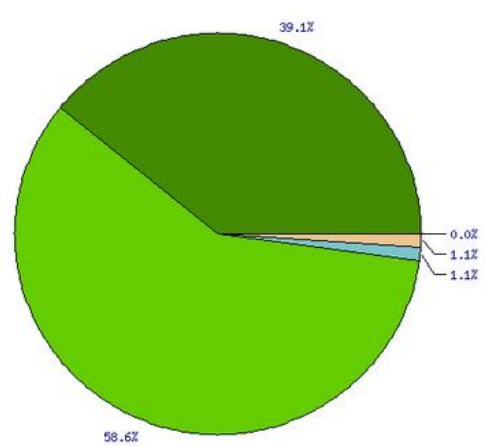

\section{Sangat Puas} Tidak Puas
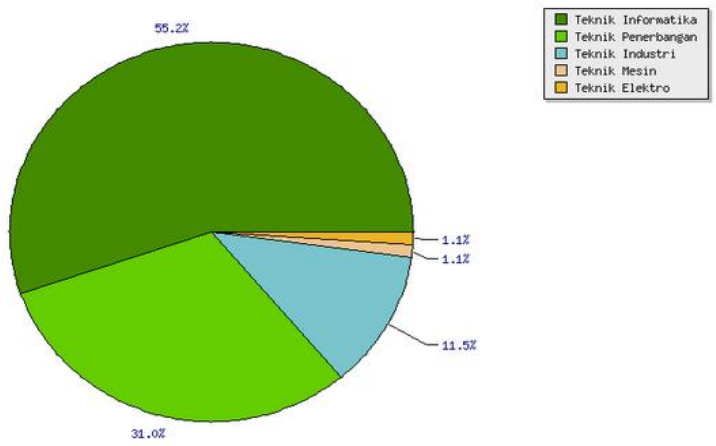

Gambar 17. Detail Tingkat Efisiensi Sistem

Gambar 18. Tingkat Kepuasan Pengguna Sistem

\section{Kesimpulan}

Dari hasil jajak pendapat yang dilakukan, diperoleh kesimpulan bahwa sistem pakar rekomendasi peminjaman buku di perpustakaan STT "Adisutjipto" Yogyakarta dengan metode penyaringan kolaboratif ini efektif, dapat meningkatkan efisiensi kinerja perpustakaan dalam hal pemberian rekomendasi buku berdasarkan profil pengguna dan buku yang dipinjam, serta dapat menghasilkan rekomendasi buku yang memuaskan.

\section{Daftar Pustaka}

Al-Bahra, Ladjamudin. 2005. Analisis dan Desain Sistem Informasi. Yogyakarta: Graha Ilmu.

Buono, P., Costabile, M.F., Guida, S., Piccinno, A., Tesoro, G., 2000,Integrating User Data and Collaborative Filtering in a Web Recommendation System, Journal of Dipartimento di Informatica, Universita di Bari, p. 1-12.

Kumar, A., Thambidurai, P., 2010, Collaborative Web Recommendation Systems - A Survey Approach, Global journal of Computer Science and Technology, Vol. 9 Issue 5 (Ver. 2.0), p. 30-35. 
Liang, T.P., Lai, H.J., Ku, Y.C., 2007. Personalized Content Recommendation and User Satisfaction: Theoretical Synthesis and Empirical Findings,Journal of Management Information Systems, ME Sharp, Inc., Vol. 23, No. 3, pp. 45-70.

Turban E., Aronson J.E., Liang T.P., 2003, Decision Support Systems and Intelligent Systems (Sistem Pendukung Keputusan dan Sistem Cerdas). Yogyakarta : Andi Offset. 